\title{
Urban identity and tourism: different looks, one single place
}

Fátima Bernardo PhD

Assistant Professor, Department of Psychology, School of Social Sciences, University of Évora, Évora, Portugal; Research Fellow, CESUR-CERIS,

University of Lisbon, Lisbon, Portugal

(corresponding author: fatimab@uevora.pt)

Joana Almeida PhD

Assistant Professor, Department of Civil Engineering, Architecture and

Georesources, Instituto Superior Técnico, Lisbon University, Lisbon,

Portugal; Research Fellow, CESUR-CERIS, University of Lisbon, Lisbon,

Portugal

\section{Catarina Martins MSC}

Master Student, Urban Planning and Territorial Management, Instituto

Superior Técnico, University of Lisbon, Lisbon, Portugal

\begin{abstract}
'Urban identity' is high on the policy agenda and pervades the discourse of the planning community on the value of historical city centres. Unfortunately, there seems to be, until today, no proposal in scholarly literature of any unified conceptual framework or any tools to make identity operational. 'Tourism' takes advantage of this process, by seeking the qualities of the place, its authenticity and its perceived uniqueness that is grounded on the physical features as well as on the presence of local communities - their way of living and investing in the place. The interdependence between identity as perceived by tourists (external observer) and the identity of the residents rooted in the relationship with the place (in-group) are key to addressing the identity of historic urban areas. These issues are addressed in the context of the growing attractiveness of Lisbon, Portugal, using a historic neighbourhood as a case study. The findings, which are on a set of interviews with different groups of users, showed the points of convergence and divergence between the different groups' views of the neighbourhood's identity. This actor-oriented approach is pivotal to understanding the process and to produce knowledge for informed action.
\end{abstract}

\section{Introduction}

\subsection{Urban identity: different approaches, one place}

The concept of urban identity is present in the discourse of politicians, practitioners and researchers from different disciplines, with a wide variety of conceptualisations and definitions. However, despite the increasing use of this concept, and the recognition of its importance for urban planning (Palmer et al., 2013), current scholarship has not proposed any conceptual framework or tools to make the identity operational (Loupa-Ramos et al., n.d.). The different meanings presented in the literature may cause confusion and weaken its importance.

The identities of places are depicted in the literature in different ways depending on the objective and the field involved. On one hand, the urban identity is mainly centred on the physical features of the place, including the physical elements and the way they are organised. This conceptualisation, also called spatial identity, refers to the environmental features that allow one place to be distinguished from another (Lynch, 1960).
This is an expert-based approach that is centred on the observer's point of view.

On the other hand, urban identity is conceptualised as not only the spatial character of the place but also including the memories and the symbolic meanings associated with the setting (both personal and socio-cultural). Identity in this sense refers to the characteristics of the place as perceived by people. This approach focuses on the point of view of different users.

Two points of view can thus be distinguished: one by which a place is seen as a source of identity and as contributing to the collective identity of its residents (Bernardo and Palma, 2012) and a second, the external observer's viewpoint that focuses on what makes a place unique. Some attempts to integrate these two perspectives from a theoretical perspective rather than from the practical one can be found in the literature (e.g. Loupa-Ramos et al., n.d.).

The main objective of this paper is to present a conceptualisation of urban identity that emphasises the importance of 


\section{Offprint provided courtesy of www.icevirtuallibrary.com Author copy for personal use, not for distribution}

including both perspectives and thus sheds light on the impact of tourism development on that identity.

\subsection{Urban identity: capture its contents}

The contents of identity comprise the meaning of collective identity - that is, the physical and social characteristics of a place that determine the perceived uniqueness of their residents and observers (tourists). When one identifies with a place, this is accompanied with a self-stereotype that includes values and norms associated with this category, and the behaviour is consistent with the contents of the category (e.g. Brown, 2000). Similarly, when an observer identifies a place with a specific identity, this identity is based on the meaningful contents that make the place unique. The process of identifying uses elements that are perceptually salient and elements that facilitate the process of positive distinctiveness (Loupa-Ramos et al., n.d.).

Understanding the contents is crucial to realise the extent to which changes in places can affect the identity of residents (e.g. Gu and Ryan, 2008; Twigger-Ross and Uzzell, 1996). For instance, the process of urban renovation of the London Docklands revealed the impact of changes on the main aspects of its identity, namely on the continuity, self-esteem, distinctiveness and self-efficacy (e.g. Twigger-Ross and Uzzell, 1996). As a consequence, the changes to the place demanded a restructuring of its identity by the residents who had identified more intensely with the place (Wang and Chen, 2015).

Furthermore, social changes within a space can be seen as threats to identity. Research on the context of compulsory relocation (Bernardo and Palma-Oliveira, 2005; Dixon and Durrheim, 2000) has shown that the social restructuration of the community can lead to a restructuration of the place identity based on different contents.

Concerning the contents of the identity of a place, there have been some attempts to categorise them into large dimensions as history, emblems, cultural icons and physical environment (Reicher and Hopkins, 2001) or into two main groups: individual and social contents or motivations (Droseltis et al., 2010). From a more qualitative and anthropological approach, Gustafson (2001) developed a study into the spontaneous attribution of meaning to places. In this study, he found that the answers of respondents could be mapped in a triangular model, with three interconnected poles: 'I', 'other' and 'environment'. Recent and still unpublished work on the contents of place identity carried out in a survey in the metropolitan area of Lisbon (Coelho, 2014) points out that there may be multiple dimensions of identity that can be organised into four main categories: urban structure, environmental, individual and social (Figure 1).

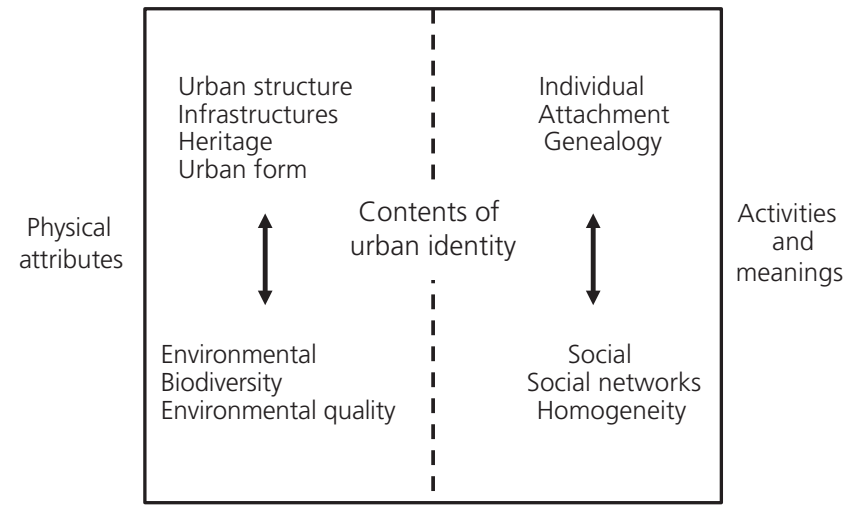

Figure 1. Contents of identity

The first two categories refer to the physical characteristics of the place; however, it is possible to distinguish between the urban structure aspects (e.g. infrastructures, heritage and urban form), and the environmental issues that include the biodiversity and environmental quality of the space (e.g. noise and pollution).

The physical characteristics are usually analysed as the scenario for social interrelationships (Stedman, 2003). In this sense, there is a heated discussion on the importance of the urban structure and infrastructures as a support to promote social interaction (Bernardo and Palma-Oliveira, 2012). Furthermore, the physical characteristics of a place are important factors that determine place identity and satisfaction (e.g. Coelho, 2014; Scannell and Gifford, 2010).

The individual category is the result of the individual interaction with a specific place. This category is anchored to the emotional connection with the place, which includes the personal history and memories, the generational rootedness (Lewicka, 2010), the perceptive dimension of familiarity with the space (Lalli, 1992) and the temporal dimension of continuity of personal past (Bernardo and Palma-Oliveira, 2005; Twigger-Ross and Uzzell, 1996). The individual connection appears associated, in the literature, with variables such as the length of residence, mobility, social identity and age (Hernandéz et al., 2007; Lewicka, 2011).

The social category includes the aspects of the place that are the result of a social construction, the product of a shared behaviour and cultural processes. There are internal and external factors to be considered in this category. The internal factors include the close ties with the neighbours or generational rootedness (e.g. Lewicka, 2011), traditions and social events (Low, 1992) and the perception of social homogeneity 


\section{Offprint provided courtesy of www.icevirtuallibrary.com Author copy for personal use, not for distribution}

(Bonaiuto et al., 2006). The external factors include the prestige and the external image of the place (Valera and Guàrdia, 2002).

Despite the interrelationship of the physical properties of a place and the activities and the meanings associated with these activities in the places (Canter, 1977), it is possible to organise the four categories of identity contents into two main groups. The first associated with the physical attributes of the space, which includes the functional and environmental contents, and the second associated with the users' relationship with the space - that is, the activities and the individual and social meanings of these activities on the place.

\subsection{Urban identities: different people, different identities}

It can be conceptualised that a place may acquire as many identities as actors. In fact 'the content of identities is neither fixed nor predetermined' (Abdelal et al., 2006: p. 6). It can change over time or at one and the same moment and it can be different for different groups with different kinds of space appropriation. Finally, even if a group shares a collective perception of a place, there is always a certain degree of discrepancy between the individuals, and especially between an individual and the group (Palmer et al., 2013; Wang and Chen, 2015). In fact, in an urban place with strong touristic attractiveness and as regards its identity, two different groups should be considered: the inside point of view and the outside point of view (Figure 2). The people who live or work in the place are considered to have an inside point of view and those who are tourists, experts and decision-makers have an outside point of view.

The different groups that capture the urban identity of a place are characterised by a set of parameters. First of all, their different social and cultural backgrounds and different degrees of expertise in urban issues are taken into consideration, and thus a distinction between users and experts becomes clear.

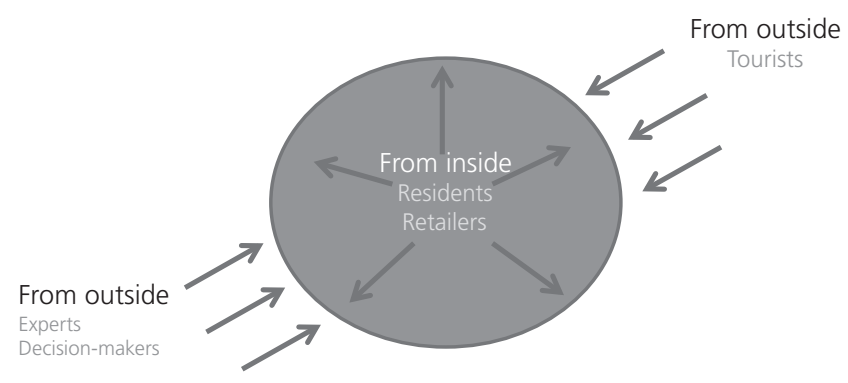

Figure 2. Urban identity from different perspectives
Second, the level of involvement or penetration in the setting (Barker, 1987) is considered. There are different degrees of penetration to be considered, which can vary from minimum involvement of a simple observer, followed by the observer with some degree of identification with the place (e.g. residents of another neighbourhood, but the same city, who consider the area an important setting to the city identity), to the maximum involvement as typical of residents who strongly identify with the site, or that of stakeholders or formal leaders. The degree of penetration is connected with length of occupation, degree of attachment, degree of ownership, extension of experience and knowledge of the setting. There is a distinction between tourists and residents to consider in this point.

It is expected that different degrees of involvement are connected with different ways of capturing the urban identity. In this sense, places can be perceived with different meanings and identities, and these are often contradictory and competing (Harner, 2001). For instance, the existence of a natural park can be threatened by some traditional rural practices that are also important elements of place identity. In places showing strong tourist attractiveness, some aspects have been explored: the relationship between the identity of residents and the welcoming of tourists presence ( $\mathrm{Gu}$ and Ryan, 2008), the emerging conflicts between the two groups and finally, the actual tourist as part of the residents' identity (Palmer et al., 2013).

While there is significant research on the impact of tourism on the identities of local communities (e.g. Ryan and Cooper, 2004; Waitt, 2003), very little research has so far addressed the impact of tourism development on the contents of identity and therefore the study of this impact needs further exploration in order to understand what determines the acceptance of the contents change. Relative to this question, several studies have shown discrepancies between advertising images that promote several tourism destinations and the residents' identity (Ollins, 2000). Consequently, residents fail to identify with what advertising images portray (Palmer et al., 2013).

\subsection{Urban identity and tourism}

The main aspects that tourists value most in urban tourism is the place's authenticity and uniqueness (TdL, 2013a) - that is, its identity. The interdependence between tourism growth and identity preservation and enhancement is evident, and there is significant research in the literature on the impacts of tourism on local communities and heritage. Three research areas have addressed this topic.

The first research area focused on the environmental, economic and the socio-cultural impacts of tourism (Archer et al., 2005; Mason, 2003; Oviedo-Garcia et al., 2008; Swarbrooke, 1999). 


\section{Offprint provided courtesy of www.icevirtuallibrary.com Author copy for personal use, not for distribution}

These authors stress some positive and negative impacts of tourism on the identity of urban heritage places.

The second research areas focused on the residents' perception of tourism impacts (Andereck et al., 2005; Besculides et al., 2002; Tosun, 2002) and more recently the focus has been on gaining the support of residents for tourism development and planning (Oviedo-Garcia et al., 2008; Palmer et al., 2013). Oviedo-Garcia et al. (2008) concluded that gaining the support of residents was essential for managers responsible for planning tourism and its development. Palmer et al. (2013) highlighted the need to involve residents with tourism so that the residents can become tourism ambassadors for their communities.

Finally, some research investigated the conflicts between heritage conservation and tourism development and how planning can reconcile these two conflicting aspects (Campbell, 1996; Jepson, 2001; Nasser, 2003). The relationship between tourism development and local communities is sometimes conflictual, as tourism development poses threats to the existing place values, ways of life and the place attachment, which are important components of place identity ( $\mathrm{Gu}$ and Ryan, 2008; Healey, 2005). The comprehensive vision planning between heritage conservation and tourism development is also carried out by Al-hagla (2010), who defined a master planning process that balances all of the development aspects. Besides, in a recent research publication, Wang and Chen (2015) emphasise the importance for urban planners to develop strategies that are congruent with resident's self-concept of place identities.

Considering this approach to urban identity that emphasises the importance of including different perspectives, the main objective is, through the use of a case study, to understand the impact of tourism development on the urban identity of a place by answering the following questions: $(a)$ What are the contents that shape peoples' place identity as well as the identity of the place? $(b)$ How do these multiple identities converge and diverge in terms of place identity contents? and $(c)$ What are the main conflicts between tourism development and urban identity preservation?

These questions are addressed in the context of the growing attractiveness of Lisbon, Portugal, using as a case study a historic neighbourhood of this city - the Alfama neighbourhood.

\section{Method}

It is evident that the analysis focused on the conflict between the preservation of the place's identity and tourism growth. This is why the historic and tourist neighbourhood of Alfama - Lisbon - is the one chosen (Figure 3).

\section{$2.1 \quad$ Case study}

Alfama is part of the ancient town centre of Lisbon, which is usually known as a historical or popular neighbourhood. As pointed out by Cordeiro et al. (1999)

... [Alfama] is possibly used most frequently among urban references for the symbolic construction of the typical image of Lisbon.

Alfama is situated on the banks of the river Tagus. The neighbourhood extends over one of Lisbon's hills, especially on the south flank, spreading down from the São Jorge Castle to the riverside.

Alfama has been the very heart of the city of Lisbon's development since the Roman settlement, and later under Moorish government, from the eighth century onwards, a period that left stretches of city wall.

The Alfama's urban texture derives from the Muslim period, even though the 1755 earthquake caused destruction. The rebuilding kept the previous typology of the layout: the narrow alleys, the pathways and the stairs (Costa, 1985).

[...] the houses are old, small and poor. There are many aristocratic palaces and old bourgeois mansions scattered over the place. The space is quite closed in itself, without broad or straight streets crossing it. One steps into the neighbourhood as if it were a separate world, shielded against the movement of the surrounding city. Within this closed world there is a density, intensity and repetition of the daily interaction of its inhabitants. The streets are frequently used - women meet there, they are children's playgrounds and the arena of men's conversations. Busy night life especially during the hot season: chatting, dancing and fado singing.

In short, the Alfama neighbourhood has a series of problems related to the characteristics of its building heritage, to the tourism services on offer and to its inhabitants. These facts underlie its potential value as a case study for this research.

The fact that urban regeneration is being almost exclusively oriented towards tourist accommodations has been the target of strong criticism on the grounds of a potential loss of Alfama's density, both by residents and the general public. In addition, the Lisbon City Council is not monitoring this growth.

Considering that the latent conflict between tourism growth and heritage preservation has escalated to a serious problem, the choice of a research based on a single case study is justified. It is defined as rare and exclusive by Yin (2009: pp. 47-49), or as extreme by Flyvbjerg (2006: p. 221), and it requires finding ways to tackle effectively such a problem. 

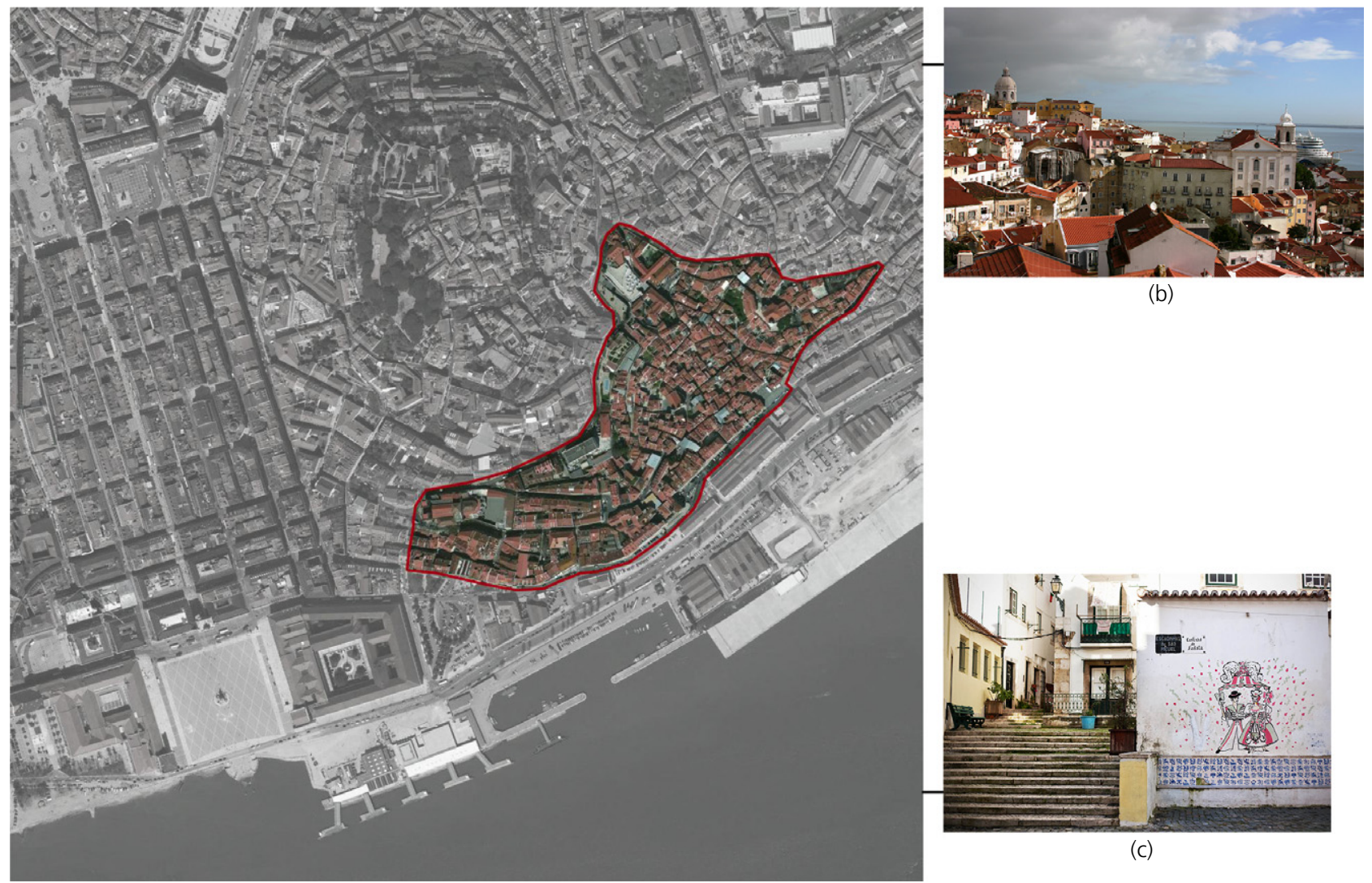

(b)

(a)

Figure 3. The district of Alfama. (a) Alfama's neighbourhood, bing maps, April 2015. Microsoft product screen shot reprinted with permission from Microsoft Corporation. (b) View over Alfama from 'Portas do Sol', Faria, March 2015. (c) Stair 'Escadinhas de São Miguel, Faria, March 2015

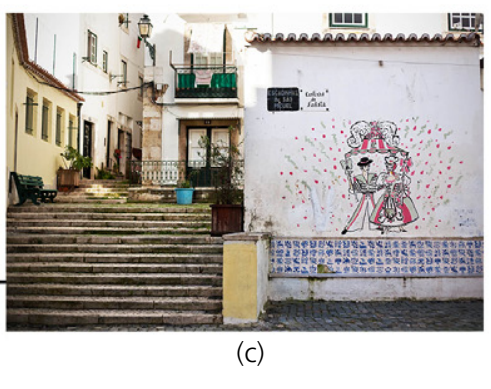

\subsection{Participants, instruments and procedures}

The stakeholders were divided into four groups in the interviews: (a) residents, (b) retail and hotel industry (from an inside perspective), $(c)$ tourists and $(d)$ decision-makers (from an outside perspective). Six public authorities, responsible for policies and interventions that affected the Alfama, were contacted (entities responsible for managing the heritage and developing tourism), and requested to take part in the interviews. These six interviews took place in March 2014.

The other three groups (residents, retail and hotel industry, and tourists) were interviewed in six of the most important (busiest) streets across the neighbourhood in March and April. In this fieldwork, interviewees were asked to suggest other people to be interviewed (snowball technique). Apart from the six interviews with the public authorities, 125 interviews were conducted: 52 with residents, 34 with members of the retail and hotel industry, and 39 tourists. Despite attempting a gender balance, $60 \%$ of the interviewees were women. The tourists, who were interviewed, came from different countries
(Belgium, Brazil, USA, France, Germany, Ireland, Italy, Norway, Poland, Portugal, Scotland, Spain and Switzerland). Out of the residents who were interviewed, $70 \%$ were over 55 years of age. Furthermore, although a balance of recent and long-term residents was intended (periods of residence longer than 20 years), $80 \%$ of those questioned were long-term residents. The interviews were conducted by two people, one who listened carefully and the other who took notes.

To answer the research questions, the stakeholders were asked the following two questions.

What are the elements of Alfama's identity?

- What are the main problems related to Alfama's tourism growth?

A content analysis procedure was used. The answers were divided into segments with significance concerning the questions. Coded segments may include phrases or words (e.g. 'strong social networks' or 'solidarity'). The researchers created 


\begin{tabular}{|c|c|c|c|c|c|}
\hline & Residents & $\begin{array}{l}\text { Retail and } \\
\text { hotel industry }\end{array}$ & Tourists & $\begin{array}{c}\text { Decision- } \\
\text { makers }\end{array}$ & Total \\
\hline \multicolumn{6}{|l|}{ Urban structure } \\
\hline Urban form & $35(67 \%)$ & $22(65 \%)$ & $29(74 \%)$ & - & 86 \\
\hline Urban scale & $16(31 \%)$ & $10(29 \%)$ & - & - & 26 \\
\hline \multicolumn{6}{|l|}{ Urban features } \\
\hline Antique/old & $10(19 \%)$ & $11(32 \%)$ & $19(49 \%)$ & - & 40 \\
\hline Authenticity & $4(8 \%)$ & - & $33(85 \%)$ & - & 37 \\
\hline \multicolumn{6}{|l|}{ Heritage } \\
\hline Tiles & $5(10 \%)$ & - & - & $2(33 \%)$ & 7 \\
\hline 'The birth of Lisbon' & - & $7(21 \%)$ & - & $3(50 \%)$ & 10 \\
\hline Monuments & - & - & - & $6(100 \%)$ & 6 \\
\hline \multicolumn{6}{|l|}{ Infrastructures } \\
\hline Traditional commerce & - & $22(65 \%)$ & $20(51 \%)$ & - & 42 \\
\hline \multicolumn{6}{|l|}{ Social } \\
\hline 'Ways of life' & - & - & - & - & - \\
\hline Life on the streets & $22(42 \%)$ & $15(44 \%)$ & $23(59 \%)$ & - & 60 \\
\hline Street decoration & - & $10(29 \%)$ & $22(56 \%)$ & - & 32 \\
\hline Drying clothes in the street & - & - & 15 (39\%) & - & 15 \\
\hline Strong social networks & $30(58 \%)$ & $18(53 \%)$ & - & - & 48 \\
\hline \multicolumn{6}{|l|}{ People } \\
\hline Socio-cultural character & - & $8(24 \%)$ & - & - & 8 \\
\hline Solidarity & $18(35 \%)$ & $8(24 \%)$ & - & - & 26 \\
\hline Familiarity & $19(37 \%)$ & $10(29 \%)$ & - & - & 29 \\
\hline Friendly & - & - & $18(46 \%)$ & - & 18 \\
\hline Security perception & - & - & 15 (39\%) & - & 15 \\
\hline Social authenticity & - & $17(50 \%)$ & $31(80 \%)$ & - & 48 \\
\hline Festivities & $20(39 \%)$ & $14(44 \%)$ & 15 (39\%) & - & 49 \\
\hline 'Fado' taverns & - & - & $13(33 \%)$ & - & 13 \\
\hline \multicolumn{6}{|l|}{ Individual } \\
\hline 'Place of birth' & - & $18(53 \%)$ & - & - & 18 \\
\hline \multicolumn{6}{|l|}{ Tourism relationship } \\
\hline Touristic place (easy coexistence) & $25(48 \%)$ & $15(44 \%)$ & - & - & 40 \\
\hline Friendly with tourists & - & - & $20(51 \%)$ & - & 20 \\
\hline Total of answers & 204 & 205 & 273 & 11 & 693 \\
\hline Number of subjects & 52 & 34 & 39 & 6 & 131 \\
\hline Mean (answers/subject) & 3.9 & $6 \cdot 0$ & $7 \cdot 0$ & $1 \cdot 8$ & - \\
\hline
\end{tabular}

Table 1. Identity contents identified in the interviews (frequencies and percentages)

initial codes based on prior research (Coelho, 2014). Three independent persons (two of them with no information about the research subject and objective) classified the sentences. The interjudge agreement was $85 \%$. All disagreements were resolved in discussion.

\section{Results}

The results were organised into two main topics, identity contents and problems related to tourism growth. Table 1 provides information on the frequencies and percentages of identity contents by stakeholders and Table 2 provides information on the frequencies and percentages of problems of tourism growth in Alfama as perceived by stakeholders.

\subsection{Identity contents}

An analysis of the interviews shows a wealth of contents regarding the contents identification (Table 1) that focuses primarily on the functional and social dimensions. A total of 693 responses were identified, corresponding to an average of 3.9 answers from residents, six answers from members of the retail 


\begin{tabular}{|c|c|c|c|c|c|c|}
\hline Tourism impact & Motivations & Residents & $\begin{array}{l}\text { Retail and hotel } \\
\text { industry }\end{array}$ & Tourists & $\begin{array}{l}\text { Decision- } \\
\text { makers }\end{array}$ & Total \\
\hline No impact & Tourism growth is not a problem & $9(5 \%)$ & - & - & - & 9 \\
\hline \multirow[t]{3}{*}{ Environmental } & Lack of cleanliness & $9(5 \%)$ & - & - & - & 9 \\
\hline & New noisy tourist inhabitants & $26(14 \%)$ & - & - & - & 26 \\
\hline & Tuk-tuk pollution & $25(13 \%)$ & $10(12 \%)$ & $13(17 \%)$ & - & 48 \\
\hline \multirow[t]{5}{*}{ Economic } & $\begin{array}{l}\text { Building regeneration for tourist } \\
\text { accommodation }\end{array}$ & $26(14 \%)$ & - & - & 1 & 27 \\
\hline & Disappearance of traditional local shops & - & $5(6 \%)$ & - & 1 & 6 \\
\hline & $\begin{array}{l}\text { Higher housing and retail rents and } \\
\text { taxes }\end{array}$ & $25(13 \%)$ & $18(22 \%)$ & - & - & 47 \\
\hline & Limitations to tourism development & - & - & - & 1 & 1 \\
\hline & Tourists do not buy & - & $10(12 \%)$ & - & - & 10 \\
\hline \multirow[t]{8}{*}{ Socio-cultural } & Building degradation & $9(5 \%)$ & $5(6 \%)$ & - & - & 14 \\
\hline & Decreasing inhabitants & $9(5 \%)$ & $10(12 \%)$ & - & 1 & 20 \\
\hline & Lack of security & $35(18 \%)$ & $14(17 \%)$ & - & - & 49 \\
\hline & Large tourist group/many tourists & $17(9 \%)$ & $5(6 \%)$ & $26(33 \%)$ & - & 48 \\
\hline & Loss of authenticity & - & $5(6 \%)$ & $13(17 \%)$ & 1 & 19 \\
\hline & Works in buildings & - & - & $26(33 \%)$ & - & 26 \\
\hline & Poor quality of urban regeneration & - & - & - & 1 & 1 \\
\hline & Total of answers & $190(100 \%)$ & $82(100 \%)$ & $78(100 \%)$ & 6 & 356 \\
\hline
\end{tabular}

The results discussed in section 4 are in bold.

Table 2. Problems of tourism growth in Alfama as perceived by stakeholders (frequencies and percentages)

and hotel industry, seven from tourists and only 1.8 answers from decision-makers.

In terms of urban structure, the urban form of the neighbourhood ('it is a neighbourhood of alleys, stairways and narrow streets, with colourful tiles', said a retailer), the urban scale ('small houses, small neighbourhood, said a retailer; 'medieval scale' or 'like a village', said tourists), the perception of an old and authentic heritage and the presence of traditional commerce are the most commonly reported aspects, by residents, members of the retail and hotel industry, and tourists ('authentic', 'real', said tourists). However, the presence of monuments is only reported by decision-makers. The interviewed retailers and hotel industry operators only referred to the importance of the neighbourhood as the birthplace of Lisbon, and a few residents mentioned the tiles. Residents and tourists did not mention the building heritage of the neighbourhood.

Residents, retailers and tourists reported several aspects of the social dimension of the urban identity, particularly, the 'ways of life', the decoration of the streets, the life on the streets, the clothes hanging out on the street and the friendly character of the Alfama residents. This aspect is also categorised as 'social authenticity' as this expression is frequently used by tourists and retailers.

Concerning the similarity and differences of the identity contents reported by the different groups, the findings show answers similar to that given by residents and retailers. This can be explained by the long-standing relationship with the place by both groups, and by similar patterns of use of the place. The tourists' interviews are particularly interesting because they were strongly focused on two interdependent aspects: on one hand, they mentioned the spatial configuration of the streets and the scale of the buildings and on the other hand, they referred to the use and appropriation of streets by the residents. In fact, these two aspects are strongly connected and interdependent. The tourists paid special attention to the street decoration in terms of the recycled materials used, and the amount of residents' manual work involved.

Another social aspect referred to by tourists is the perception of security and tranquillity in the Alfama neighbourhood.

The decision-makers mainly reported on the importance of the architectural heritage. The data correspond to a survey of the 


\section{Offprint provided courtesy of www.icevirtuallibrary.com Author copy for personal use, not for distribution}

touristic sites and to the content on flyleaves: the heritage in terms of buildings is central (e.g. Moorish and medieval historic centre), followed by references to the urban structure, the immaterial heritage, such as fado taverns, and the scenic views. Nevertheless, the particular character of the neighbourhood in terms of the presence of local communities, with their way of living and the way of owning the place, are not referred to on the official tourism advertisement. By contrast, these are precisely the aspects that are stressed as important to the Alfama identity by tourists, and they are perceived as highly positive.

The final aspect underlined by the findings is the relationship between residents and tourists. In fact, both groups spontaneously reported an easy and friendly relationship, and it seems that tourism has already become a part of Alfama residents' identity. A resident said, 'The people are very friendly and know each other and it feels like tourists were born here'. Apart from being an important economic factor, it also contributes to reinforcing the self-esteem of the residents of that neighbourhood ( $\mathrm{Gu}$ and Ryan, 2008). This positive interrelationship between residents and tourists, as well as the positive view of tourists by residents, and the residents' positive perspective of tourists are important aspects to be taken into account for advocacy behaviours with respect to promoting incoming tourism (Nunkoo and Gursoy, 2012; Palmer et al., 2013).

\subsection{Problems related to tourism growth}

When asking the respondents to identify the main problems related to Alfama tourism growth, the answers were grouped into four types of stakeholders (cf. Section 2) - residents, members of the retail and hotel industry, tourists and decisionmakers. The most significant problems were organised into three main topics when analysing tourism impacts - environmental, economic and socio-cultural impacts (Archer et al., 2005; Mason, 2003; Oviedo-Garcia et al., 2008; Swarbrooke, 1999) and into a fourth group 'no impact', whenever the respondents did not recognise any impacts. As specified in Table 2, 12 types of problems were identified: tourism growth is not a problem; lack of cleanliness; new noisy tourist inhabitants; tuk-tuk pollution; buildings regeneration for tourist accommodation; disappearance of traditional local shops; higher housing and retail rents and taxes; limitations to tourism development; tourists do not buy; buildings degradation; decreasing inhabitants; lack of security; large tourist tour groups/many tourists; loss of authenticity; works in buildings (cf. Table 2).

Five different aspects can be highlighted in Table 2.

First, the most relevant problems of tourism growth in Alfama, which were identified by the respondents were tuk-tuk pollution, higher housing and retail rents and taxes, lack of security and loss of authenticity.
Second, the residents, the retailers and hotel industry groups had similar concerns about tourism growth. They highlighted the tuk-tuk pollution (they said 'the tuk-tuk are very noisy, not the electric ones'), the building regeneration for tourist accommodation ('the houses that are being refurbished are just for tourists' - one dissatisfied resident said), the higher housing and retail rents and taxes, the building degradation, the decreasing number of inhabitants, the lack of security and the large tourist groups. Specifically, the conversion from residential to tourism use seems to be one of the biggest problems. A hotelier highlighted that 'there is a loss of authenticity with the increased tourist pressure, forcing the expulsion of residents due to house price increase' and a resident emphasised: 'I am concerned about the entry and exit of so many people. My children have to leave Alfama because of the increased rent value'.

Third, only the 'retailers and hotel industry' group brought up the fact that 'tourists don't buy' ('the tourists who stay overnight, don't buy anything, they just take photographs').

Fourth, the main concerns of the tourist group were related to the socio-cultural aspects: large tourist groups, loss of authenticity and works in buildings. They also mentioned the tuk-tuk pollution.

Before presenting the final topic related to decision-makers' perception, it should be pointed out that the decision-makers' group is divided into public economic authorities and public heritage authorities.

So finally, the 'economy' insists that there should not be any limitations on tourism development 'don't limit the number of hotels, the more tourists the better'. Meanwhile these respondents were aware of the negative impact of tourism growth in city transformations: 'because of the growth of tourism, all the cities end up the same'; therefore, insisting on the importance of preserving traditional commerce (cf. Table 2). The respondents responsible for heritage public administration highlighted the poor quality of urban regeneration: 'renovation work should not be limited to the frontages, the authenticity should be maintained both inside and in the construction techniques'. The way these respondents approached the topic of loss of authenticity (Table 2) was linked to the poor quality of urban regeneration mentioned. They were also concerned about 'tourism taking over the historical centres, driving out the permanent residents and altering residential use for tourist use' (cf. Table 2).

\section{Discussion and conclusions}

Considering the literature review regarding the impact of tourism on urban identity, two main points can be highlighted. 


\section{Offprint provided courtesy of www.icevirtuallibrary.com Author copy for personal use, not for distribution}

The first point is a general consensus that tourism 'trades on the physical, social, economic, environmental and cultural character of special places' (Williams, 2002). Nevertheless, the relationship between tourism development and the local communities is often conflictual, and poses threats to the existing place identity ( $\mathrm{Gu}$ and Ryan, 2008; Healey, 2005). Therefore, one of the aims of this approach is to assist in the understanding of the conflictual nature mentioned, through the assessment of the urban identity of different users (residents, tourists etc.), based on the meaningful contents that are rooted in the physical and social features of the place as well as in the individual experience of the place.

Moreover, this approach also intends to shed light on the impact of changes on the structure of place identity perceived by different groups and might assist in predicting the residents' ability to integrate these changes.

The second point is that tourism promoters at different levels are involved in promoting place identity to attract tourists (Dredge and Jenkins, 2003), and the 'authenticity' of the place was the most important factor identified by tourists who visited Lisbon (TdL, 2013b). The findings of this study, backed up by other recent literature (e.g. Wang and $\mathrm{Xu}, 2015$ ), imply that tourism organisations promote place identity not only to tourists, but also to the local residents.

In this sense, one practical implication that can be drawn from this study is that planners and managers should recognise the importance of being aware of what attracts tourists as well as how tourism development affects the urban identity of the local residents. As aforementioned, different users can have different identities, centred in different contents, for one single place. The challenge for tourism development strategies must be centred on the congruence between these different identities, in order to maintain the place's authenticity (Wang and Chen, 2015).

The findings of this exploratory study on this historic Lisbon neighbourhood accentuate the importance of understanding the urban identity from different perspectives. According to what was mentioned in the introduction, the ability to understand the urban identity of a place implies the inclusion of both perspectives: an inside perspective capturing the contents associated with the urban identity of residents and local stakeholders and an outside perspective, capturing the elements that contributed to the perceived identity of the place by tourists or decision-makers.

The findings show a particular similarity in residents, shop owners (inside perspective) and tourists' identity perception (outside perspective). All perspectives emphasise the significance of the social characteristics of Alfama's identity, namely the way of life, appropriation of the neighbourhood by the residents in terms of decoration and the use of the streets for social interaction as well as for some domestic activities such as 'drying clothes in the street'. The authenticity of the neighbourhood is also accentuated, both in terms of architecture and social action patterns. However, little reference was made to building heritage, except for the immaterial heritage - the fado tradition.

The findings also report an easy-going, friendly relationship between residents and tourists. Nevertheless, the increase in tourism has brought about several problems identified by residents. Therefore, urban tourism planners and managers should not only be well aware of what attracts tourists, but also of the type of tourism development that enhances residents' sense of self-esteem (Wang and Chen, 2015).

As Blichfeldt (2005: p. 394) emphasises 'residents - and interactions with such residents - are essential elements of place brands'. Thus, the results of this study suggest that urban tourism planners and managers must involve residents in the touristic activities and developments, enhancing the place identity, and thus the sense of belonging, and welcoming tourists.

Taking into account the findings shown in Table 2 and referring back to the specific part of the literature review mentioned in Section 1, which focuses on urban identity and tourism, three research areas can be identified: the impacts of tourism on the city, residents' perception and the conflicts between the increase in tourism and the preservation of heritage, highlighting the relevant aspects, conclusions and future research.

The impacts highlighted by the respondents are somehow pointed out in the literature review on the topic of tourism impacts (Archer et al., 2005; Mason, 2003; Oviedo-Garcia et al., 2008; Swarbrooke, 1999). The main finding of this research is the perceptions of the different groups.

For example, decision-makers were not concerned with the question of the tuk-tuk in the historical parts of Lisbon until the date of the interviews and did not have any policy for their operation in the city. Nor was there a public policy for managing the movements of large groups of tourists in the city's older neighbourhoods such as Alfama. This situation is going to be exacerbated with the cruise ship terminal planned for this part of the city. The findings also show that the conversion of homes into tourist accommodation in Alfama is not a problem for the public administration. This is one of the negative impacts that is widely discussed in the literature (cf. Section 1), but the public entities have no policies or strategic action plan to minimise this negative impact. 


\section{Offprint provided courtesy of www.icevirtuallibrary.com Author copy for personal use, not for distribution}

Regarding the residents' perception, there is an increased pressure exerted on them to participate in the decisionmaking processes as mentioned (Oviedo-Garcia et al., 2008; Palmer et al., 2013). It should be noted that this was the only group that mentioned the negative impacts of tourism growth concerning the building regeneration for tourist accommodation such as new noisy tourist inhabitants and lack of cleanliness. These negative impacts are also taking place in other areas of Lisbon; therefore, there is an urgent need to develop new urban policies and conflict management strategies.

The following conclusions may be drawn from the findings.

First, it would be important to carry out additional research into the urban rehabilitation that is taking place in these historical neighbourhoods, especially in terms of the authenticity that tourists find particularly attractive (cf. Table 2 and TdL, 2013a).

Second, it can be concluded that authenticity seems to be wrapped up in an ideal image in which buildings remain untouched by time and traditional shops and quietness abound (no tuk-tuk noise or noise of tourist groups). Consequently, there are strong grounds to consider that the awareness of different perspectives on authenticity should be researched further.

Finally, and focusing specifically on the particular relevance of this study for urban planning, a more active intervention on the part of Lisbon Municipality is highly recommended, namely through more incentives for urban renewal for residential purposes and an increased monitoring of Alfama urban and social development. This on-site monitoring by a municipal technical team, who recognises the existing problems, is crucial, and therefore allowing a more preventive action.

It is also important to note that this study is limited by its exploratory nature. Due to the reduced sample size, it is not representative of the neighbourhood. This study is also limited by the way interviews were conducted, and the way the data were collected. Interviews should be recorded in future studies.

\section{REFERENCES}

Abdelal R, Herrera YM, Johnston Al and McDermott R (2006)

Identity as a variable. Perspectives on Politics 4(4): 695-711.

Al-Hagla KS (2010) Sustainable urban development in historical areas using the tourist trail approach: a case study of the Cultural Heritage and Urban
Development (CHUD) project in Saida. Lebanon Cities 27(4): 234-248.

Andereck KL, Valentine MK, Knopf RC and Vogt CA (2005) Residents' perceptions of community tourism impacts. Annals of Tourism Research 32(4): 1056-1076.

Archer B, Cooper C and Ruhanen L (2005) The positive and negative impacts of tourism. In Global Tourism, 3rd edn (Theobald WF (ed.)). Elsevier Butterworth-Heinemann, Burlington, MA, USA, pp. 79-102.

Barker RG (1987) Prospecting in environmental psychology: Oskaloosa revisited. In Handbook of Environmental Psychology (Stokols D and Altman I (eds)). John Wiley, New York, NY, USA, vol. 2, pp. 1403-1432.

Bernardo F and Palma-Oliveira JM (2005) Place change and identity processes. Medio Ambiente y Comportamiento Humano 6(1): 71-87.

Bernardo F and Palma-Oliveira JM (2012) Place identity: a central concept in understanding intergroup relationships in the urban context. In The Role of Place Identity in the Perception, Understanding, and Design of Built Environments (Casakin $\mathrm{H}$ and Bernardo F (eds)). Bentham, Danvers, MA, USA, pp. 35-46.

Besculides A, Lee ME and McCormick PJ (2002) Residents' perceptions of the cultural benefits of tourism. Annals of Tourism Research 29(2): 303-319.

Blichfeldt BS (2005) Unmanageable place brands? Place Branding 1(4): 399-401.

Bonaiuto M, Formara F and Bonnes M (2006) Perceived residential environmental quality in middle and low extension Italian cities. Revue Européenne de Psychologie Appliquée 56(1): 23-34.

Brown R (2000) Social identity theory: past achievements, current problems and future challenges. European Journal of Social Psychology 30(6): 745-778.

Campbell S (1996) Green cities, growing cities, just cities? Urban planning and the contradictions of sustainable development. Journal of the American Planning Association 62(3): 296-312.

Canter D (1977) The Psychology of Place. Architectural Press, London, UK.

Coelho R (2014) Lugares Que se Constroem: Identidade e Conteúdos da Identidade de Lugar. Um Estudo no Periurbano da Area Metropolitana de Lisboa. Unpublished MSc thesis, University of Évora, Évora, Portugal (in Portuguese).

Cordeiro Gl, Costa AF and Velho G (1999) Bairros: contexto e intersecção. In Antropologia Urbana: Cultura e Sociedade no Brasil e em Portugal (Velho G (ed.)). Zahara, Rio de Janeiro, Brasil, pp. 58-79 (in Portuguese). 


\section{Offprint provided courtesy of www.icevirtuallibrary.com Author copy for personal use, not for distribution}

Costa AF (1985) Espaços urbanos e espaços rurais: um xadrez em dois tabuleiros. Análise Social XXI: 735-756 (in Portuguese).

Dixon J and Durrheim K (2000) Displacing place identity: a discursive approach to locating self and other. British Journal of Social Psychology 39(1): 27-44.

Dredge D and Jenkins J (2003) Destination place identity and regional tourism policy. Tourism Geographies 5(4): 383-407.

Droseltis O, Vivian L and Vignoles V (2010) Toward an integrative model of place identification: dimensionality and predictors of intrapersonal-level place preferences. Journal of Environmental Psychology 30(1): 23-34.

Flyvbjerg B (2006) Five misunderstandings about case-study research. Qualitative Inquiry 12(2): 219-245.

Gu H and Ryan C (2008) Place attachment, identity and community impacts of tourism. Tourism Management 29(4): 637-647.

Gustafson P (2001) Meaning of place: everyday experience and theoretical conceptualizations. Journal of Environmental Psychology 21(1): 5-16.

Harner J (2001) Place identity and copper mining in Sonora, Mexico. Annals of the Association of American Geographers 91(4): 660-680.

Healey P (2005) Place, identity and governance: transforming discourses and practices. In Habitats: A Sense of Place, 2nd edn (Hillier J and Rooksby E (eds)). Ashgate, Aldershot, UK, pp. 189-218.

Hernandéz B, Hidalgo MC, Salazar-Laplace ME and Hess S (2007) Place attachment and place identity in natives and no-natives. Journal of Environmental Psychology 27(4): 310-319.

Jepson EJ (2001) Sustainability and planning: diverse concepts and close associations. Journal of Planning Literature 15(4): 499-510.

Lalli M (1992) Urban related identity: theory, measurement and empirical findings. Journal of Environmental Psychology 12(4): 285-303.

Lewicka M (2010) What makes neighborhood different from home and city? Effects of place scale on place attachment. Journal of Environmental Psychology 30(1): 35-51.

Lewicka M (2011) Place attachment: how far have we come in the last 40 years? Journal of Environmental Psychology 31(3): 207-230.

Loupa-Ramos IL, Bernardo F, Ribeiro SC and Eetvelde VV (n.d.) Landscape identity: implications for policy making. Land Urban Policy, in press.

Low SM (1992) Symbolic ties that bind. Place attachment in the plaza. In Place Attachment (Altman I and Low SM (eds)). Plenum Press, New York, NY, USA, pp. 165-185.

Lynch K (1960) The Image of the City. MIT Press, Cambridge, MA, USA.
Mason P (2003) Tourism Impacts, Planning and Management. Elsevier, Oxford, UK.

Nasser N (2003) Planning for urban heritage places: reconciling conservation, tourism and sustainable development. Journal of Planning Literature 17(4): 467-479.

Nunkoo R and Gursoy D (2012) Residents' support for tourism: an identity perspective. Annals of Tourism Research 39(1): 243-268.

Ollins W (2000) Trading Identities: Why Countries and Companies are Taking on Each Others' Roles. Foreign Policy Centre, London, UK.

Oviedo-Garcia AM, Castellanos-Verdugo M and Martin-Ruiz D (2008) Gaining residents' support for tourism and planning. International Journal of Tourism Research 10(2): 95-109.

Palmer A, Koenig-Lewis N and Jones LEM (2013) The effects of residents' social identity and involvement on their advocacy of incoming tourism. Tourism Management 38: $142-151$.

Reicher SD and Hopkins N (2001) Self and Nation: Categorization, Contestation and Mobilisation. Sage, London, UK.

Ryan C and Cooper C (2004) Residents' perceptions of tourism development: the case of Raglan, New Zealand. Tourism Review International 8(1): 1-17.

Scannell L and Gifford R (2010) The relations between natural and civic place attachment and pro-environmental behavior. Journal of Environmental Psychology 30(8): 289-297.

Stedman RC (2003) Is it really just a social construction: the contribution of the physical environment to sense of place. Society and Natural Resources 16(2): 671-685.

Swarbrooke J (1999) Sustainable Tourism Management. CABI Publishing, Wallingford, United Kingdom.

TdL (Turismo de Lisboa) (2013a) Inquérito de Satisfação e Imagem, Região de Lisboa. Observatório de Turismo de Lisboa, Portugal (in Portuguese).

TdL (2013b) Inquérito Motivacional da Cidade de Lisboa. Observatório de Turismo de Lisboa, Lisboa, Portugal (in Portuguese). See http://www.visitlisboa.com/ Observatorio.aspx (accessed 14/05/2015).

Tosun C (2002) Host perceptions of impacts, a comparative tourism study. Annals of Tourism Research 29(1): 231-253.

Twigger-Ross C and Uzzell L (1996) Place and identity processes. Journal of Environmental Psychology 16(3): 205-220.

Valera S and Guàrdia S (2002) Urban social identity and sustainability - Barcelona's Olympic Village. Environment and Behavior 34(1): 54-66.

Waitt G (2003) Social impacts of the Sydney Olympics. Annals of Tourism Research 30(1): 194-215.

Wang $S$ and Chen JS (2015) The influence of place identity on perceived tourism impacts. Annals of Tourism Research 52: $16-28$. 
Wang S and Xu H (2015) Influence of place-based senses of distinctiveness, continuity, self-esteem and self-efficacy on residents' attitudes toward tourism. Tourism Management 47: 241-250.
Williams DR (2002) Leisure identities, globalization and the politics of place. Journal of Leisure Research 34(4): 351-367. Yin RK (2009) Case Study Research: Design and Methods, 4th edn. SAGE Publications, Thousand Oaks, CA, USA.

\section{WHAT DO YOU THINK?}

To discuss this paper, please email up to 500 words to the editor at journals@ice.org.uk. Your contribution will be forwarded to the author(s) for a reply and, if considered appropriate by the editorial panel, will be published as discussion in a future issue of the journal.

Proceedings journals rely entirely on contributions sent in by civil engineering professionals, academics and students. Papers should be 2000-5000 words long (briefing papers should be 1000-2000 words long), with adequate illustrations and references. You can submit your paper online via www.icevirtuallibrary.com/content/journals, where you will also find detailed author guidelines. 